\title{
Endocarditis caused by a psittacosis agent
}

\author{
J. S. Birkhead and K. Apostolov \\ From The Division of Cardiovascular Disease in the Department of Medicine, \\ Hammersmith Hospital; and the Department of Virology, Royal Postgraduate Medical School, \\ Du Cane Road, London $W_{12}$
}

A patient is described with psittacosis endocarditis who was initially treated with tetracycline and rifampicin. Despite medical therapy aortic valve incompetence increased and aortic valve replacement was performed. Laboratory and electron microscopical studies of valve tissue confirmed that the infecting organism was a psittacosis agent.

The frequency of infection with the psittacosis agent (Bedsonia or Chlamydia psittaci) has been stressed recently (British Medical fournal, 1972). Endocarditis caused by this agent has been described by several authors (Grist and McLean, 1964; Levison et al., 1971), but only in two cases was direct diagnostic confirmation obtained, and this was from necropsy histological examination. In the patient described below the diagnosis was confirmed by demonstration of a psittacosis organism within valve tissue removed at open heart surgery and a significant fall in psittacosis/lymphogranuloma (LGV) complement-fixation titres in the serum from I: 1024 to I: I6.

\section{Case report}

The patient was a 57-year-old male gardener. He had been dyspnoeic for one year preceding investigation and this had slowly increased. Latterly he had experienced paroxysms of nocturnal dyspnoea. His brother kept a budgerigar with which he had occasionally come into contact. He had had rheumatic fever at age 20 and subsequently was passed Ar for military service. A heart murmur was first heard at a routine examination when he was 42 years old.

\section{Examination}

The patient was febrile. There was mild clubbing of fingers and toes. He was clinically anaemic. There were no splinter haemorrhages or petechiae, nor was there evidence of peripheral emboli. Blood pressure was $160 / 60 \mathrm{mmHg}$. The carotid pulses were collapsing in quality. The apical impulse was displaced $3 \mathrm{~cm}$ laterally in the fifth interspace. An early diastolic murmur, grade $2 / 4$ in length and in intensity, was heard at the left sternal edge. At the base of the heart there was a short ejection systolic murmur. The second heart sound was normal in intensity and its components moved normally with respiration. All peripheral pulses were present. The liver was enlarged ro cm below the right costal margin. The spleen was enlarged $8 \mathrm{~cm}$ below the left costal margin.

\section{Investigations}

Haemoglobin: $8.5 \mathrm{~g} / 100 \mathrm{ml}$ (hypochromic microcytic film); white cell count: $7300 / \mathrm{mm}^{3}$; erythrocyte sedimentation rate: $120 \mathrm{~mm}$ in I hour; serum electrolytes: normal; blood urea: $50-70 \mathrm{mg} / 100 \mathrm{ml}$; creatinine clearance: $55 \mathrm{ml} / \mathrm{min}$; bilirubin: $0.3 \mathrm{mg} / 100 \mathrm{ml}$; albumin: $3 \mathrm{~g} / 100 \mathrm{ml}$; globulin: $5 \mathrm{~g} / 100 \mathrm{ml}$; immunoglobulins: $\mathrm{IgG}-3900 \mathrm{mg} / 100 \mathrm{ml}$ (500-1600 mg/100 ml), IgA - I45 $\mathrm{mg} / 100 \mathrm{ml}$ (125-425 mg/100 ml), IgM - $230 \mathrm{mg} / 100 \mathrm{ml}$ (50-180 mg/100 ml); blood cultures: $\times 42-$ no growth; urine cultures: $\times 3-$ no growth; urine microscopy: red cells $2+$; antistreptolysin 0 titre: 50 units; Rickettsia burneti complement-fixation test phase $I$ and 2 titres: I:8; Psittacosis lymphogranuloma venereum group complement-fixation test: I : I024;' electrocardiogram: normal except for repolarization changes in $\mathrm{V}_{3}-6$; chest radiograph: heart grossly enlarged, some upper lobe venous distension; renal biopsy: a focal proliferative glomerulonephritis consistent with endocarditis; $\mathrm{C}_{3}$ complement level: 55 per cent; Wassermann reaction negative.

\section{Clinical progress}

On the evidence of the physical signs an endocarditis involving the aortic valve was considered to be possible. The failure to isolate any organisms from blood cultures, while not conclusive, was strongly against a bacterial aetiology. The raised complement-fixation titre for the psittacosis/lymphogranuloma group ( 1 : 1024) was strong evidence that one of these agents was responsible for his illness, and therapy was instituted on this basis.

The patient was treated with tetracycline $500 \mathrm{mg}$ 8-hourly and rifampicin $300 \mathrm{mg}$ twice daily. On this 
regimen the fever resolved and the hepatosplenomegaly receded. After four months' therapy with tetracycline and rifampicin, during which time the patient had remained relatively well, he developed increasing, and medically intractable, left ventricular failure. Though he was now no longer anaemic, there was an increased pulse pressure (160/30 $\mathrm{mmHg}$ ) and the aortic early diastolic murmur had increased in length and intensity. The aortic valve was thus excised and replaced by a StarrEdwards prosthesis. At operation the aortic valve was found to be bicuspid. The left coronary cusp was covered by firm, projecting vegetations. The right coronary cusp was less extensively involved by similar firm vegetations. After operation the patient had an uncomplicated course and is now back at work. In the six months after valve replacement the psittacosis/lymphogranuloma venereum complement fixation titres have fallen from $I: 512$ to $I: I 6$ and the immunoglobulins have also returned to normal.

\section{Microbiology}

One of the excised cusps showing typical vegetations was collected in a vessel containing Eagles' basal medium with $100 \mathrm{mg} / \mathrm{ml}$ streptomycin. One vegetation $(2 \times 3 \mathrm{~mm})$ was removed and fixed in glutaraldehyde for electron microscopy. Attempts were made to make impression smears from other vegetations, but the cell content of the smears was found to be inadequate. The rest of the vegetations were stripped off, washed, and homogenized to about ro per cent suspension in Eagles' basal medium.

The suspension was inoculated in the yolk sac of six 7-day-old chick embryos. After 6 days' incubation at $35^{\circ} \mathrm{C}$ no deaths were recorded. The smears were examined for psittacosis using Macchiavello's stain. The yolk sacs were harvested and passed twice more in the yolk sacs of chick embryos and examined. The suspension was also inoculated intraperitoneally and intracerebrally into adult mice (Meyer, 1965).

For the complement-fixation test a standard micromethod utilized in this laboratory was used. The ro per cent suspension of the vegetations was used as an antigen against patients' own serum and against standard guineapig serum provided by the Public Health Laboratories, Colindale.

Electron microscopy was performed after ultrathin sectioning of the vegetations and psittacosis infected McCoy's cells by a standard method (Apostolov and Flewett, I969).

\section{Results}

The attempts to isolate the organism in eggs and mice failed, presumably because of previous antibiotic therapy. An antigen was found in the vegetations which fixed complement with the patient's own serum (psittacosis titre $I: 5 \mathrm{I} 2$ ) and a guinea-pig hyperimmune serum. The most important finding was the demonstration of structures comparable to the psittacosis agent in the vegetations by electron microscopy (Anderson et al., 1965; Friis, 1972). Fig. I shows the appearance of typical intracellular forms of the psittacosis organism grown in McCoy's tissue culture cells. Fig. 2 shows the appearance of similar

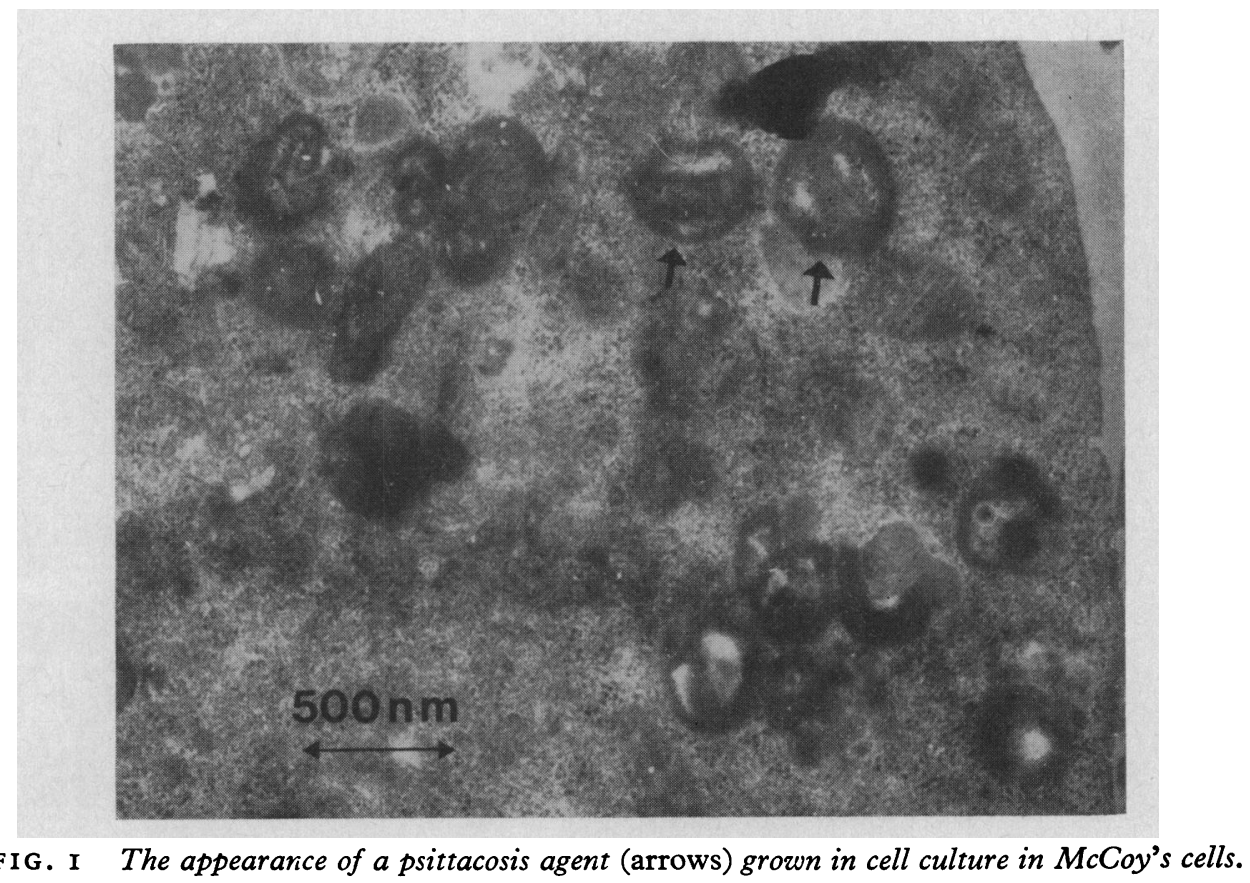


structures embedded in the fibrin matrix of a vegetation.

\section{Discussion}

It is well recognized that Chlamydia psittaci is a cardiovascular pathogen, and reports indicate that apart from endocarditis it may also cause myocarditis and pericarditis (Sutton et al., 1967). In addition to the two cases described by Levison et al. in which the diagnosis was confirmed at necropsy, there have been other less well-authenticated reports (Grist and McLean, 1964) of endocarditis caused by the psittacosis agent. It is probable that the infection involved previously abnormal valves, though Ward (197I) has discussed the possibility of infection involving previously normal valves.

In the present case there is a possibility of rheumatic damage to the valve, though the operative findings of a bicuspid valve suggest a congenital anomaly. The operative finding of firm projecting vegetations with no evidence of valve destruction is in keeping with the absence of peripheral arterial emboli in an apparently chronic illness. This is in contrast with the valve destruction and true embolic features often noted in bacterial endocarditis.

The immunoglobulin levels initially recorded are not typical of bacterial endocarditis, in which a diffuse rise of IgG, IgA, and IgM are observed (Hobbs, 1970), nor do they display the pronounced IgM rise which characterizes rickettsial endocarditis. The immunoglobulin levels recorded in this patient are similar to those seen in infection with Lymphogranuloma venereum. Lymphogranuloma venereum and Chlamydia psittaci are so antigenically similar that they cannot be distinguished by serological methods. It is not surprising that they elicit the same type of immune response. The finding that the psittacosis titres and the immunoglobulins have tended to fall pari passu may be an indication that these immunoglobulin levels are a feature of psittacosis infection. In the only other proven case of psittacosis endocarditis in which immunoglobulin levels were measured, these showed non-specific rises. The patient referred to was uraemic at the time and it may be that these values reflect the toxic suppression encountered with uraemia.

Although the patient had contact with a budgerigar, this bird was apparently healthy, and its owner did not have raised titres to the psittacosis/LGV group. It was thought that it was more likely that he had contracted the disease from infected dust encountered in his job as a gardener.

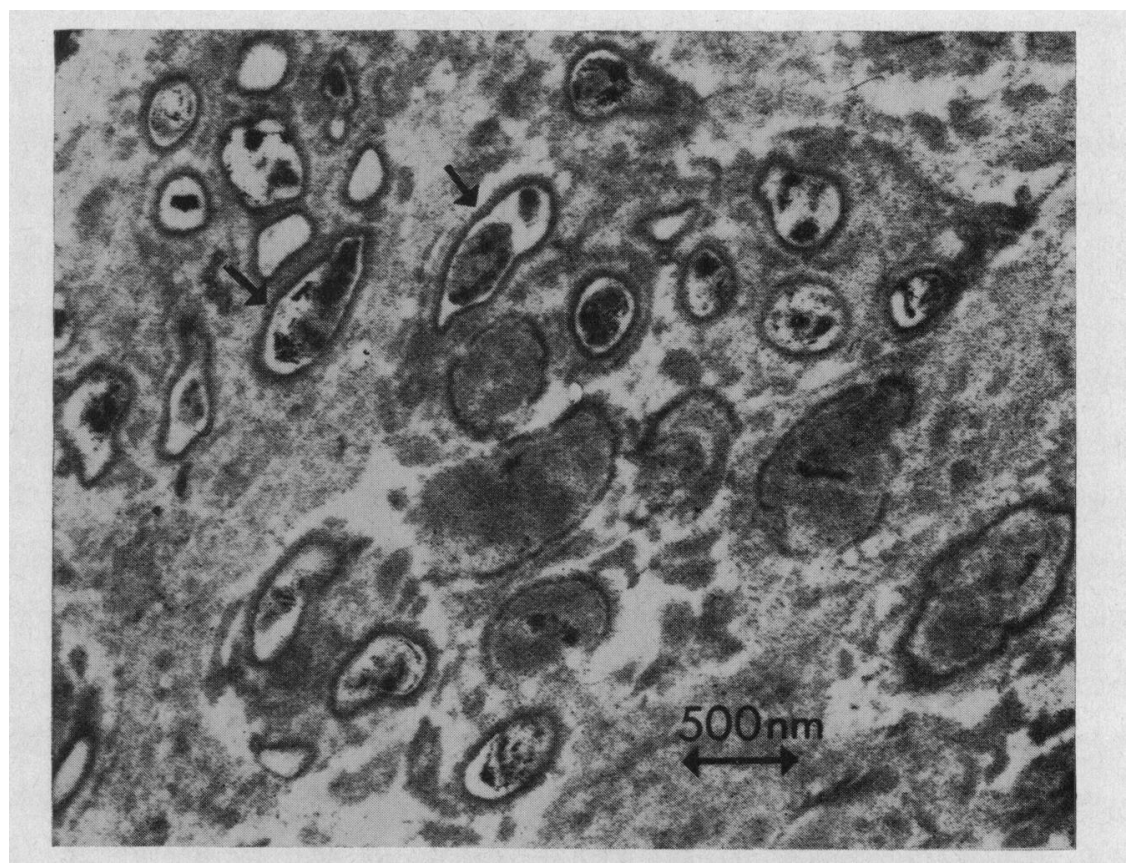

FIG. 2 A thin section of vegetation from the patient's aortic valve. A large number of structures similar in appearance to those in Fig. I are indicated by arrows. These are psittacosis ghosts embedded in fibrinous material. 
In this patient the diagnosis of psittacosis endocarditis was suspected from the high initial psittacosis/LGV complement fixation titre of $1: 1024$. After four months of antibiotic therapy this titre did not fall significantly, suggesting a persisting antigenaemia despite apparent control of the infection on other criteria. After excision of the aortic valve and thereby removal of the presumed antigenic stimulus, the psittacosis/LGV complement-fixation titre fell from $I: 512$ to $I: I 6$. This is a highly significant reduction in titre.

The failure to isolate the organism from the valve tissue is probably because of the therapy with tetracycline and rifampicin. The different morphological appearance of the organisms in the vegetations compared to those grown in tissue culture is also a reflection of antibiotic therapy (Tamura and Manire, 1968).

The direct demonstration of structures having a similar appearance to the psittacosis organism grown in tissue culture, taken in conjunction with the significant fall in complement-fixation titres, is regarded as further diagnostic proof of infection of the aortic valve with the psittacosis agent.

The authors wish to thank Professor Shillingford for his permission to publish this case. We are grateful to Professor H. H. Bentall for the aortic valve surgery and for providing the valve tissue for study. We are also grateful to Miss Celia Middlebrook who performed the serological investigations, to Professor A. P. Waterson for his criticisms of the manuscript; and to Dr. Tribe (Wellcome Foundation) who supplied psittacosis infected McCoy's cells.

\section{References}

Anderson, D. R., Hopps, H. E., Barile, M. F., and Bernheim, B. C. (1965). Comparison of the ultrastructure of several rickettsiae, ornithosis virus, and mycoplasma in tissue culture. Fournal of Bacteriology, 90, 1387 .

Apostolov, K., and Flewett, T. H. (1969). Further observations on the structure of influenza viruses $A$ and $C$. Fournal of General Virology, 4, 365.

British Medical fournal (1972). Editorial. Psittacosis. I, I.

Friis, R. R. (1972). Interaction of $L$ cells and Chlamydia psittaci: entry of the parasite and host responses to its development. Fournal of Bacteriology, $110,706$.

Grist, N. R., and McLean, C. (1964). Infections by organisms of the psittacosis/lymphogranuloma venereum group in the West of Scotland. British Medical fournal, 2, 2 I.

Hobbs, J. R. (1970). Immune globulins in some diseases. British fournal of Hospital Medicine, 3, 669.

Levison, D. A., Guthrie, W., Ward, C., Green, D. M., and Robertson, P. G. C. (I97I). Infective endocarditis as part of psittacosis. Lancet, 2, 844.

Meyer, K. F., (1965). Psittacosislymphogranuloma venereum agents. In Viral and Rickettsial Infections of Man, $4^{\text {th }}$ ed., pp. 1006-1041. Ed. by F. L. Horsfall and I. Tamm. J. B. Lippincott, Philadelphia; Pitman, London.

Sutton, G. C., Morrissey, R. A., Tobin, J. R., Jr., and Anderson, T. O. (1967). Pericardial and myocardial disease associated with serological evidence of infection by agents of the psittacosis-lymphogranuloma venereum group (Chlamydiaceae). Circulation, 36, 830.

Tamura, A., and Manire, G. P. (1968). Effect of penicillin on the multiplication of meningopneumonitis organisms (Chlamydia psittaci). Fournal of Bacteriology, 96, 875.

Ward, C. (197I). Pet birds and acquired chronic valvar disease. Lancet, 2, 546.

Requests for reprints to Dr. J. S. Birkhead, MRC Cardiovascular Unit, Royal Postgraduate Medical School, Ducane Road, London WI2. 